\title{
Customer Satisfaction Factor in Digital Content Marketing: Isparta Province as an Example
}

\author{
Ahmet Andaç ${ }^{1}$, Ferdi Akbıyık ${ }^{2}$ \& Ahmet Karkar ${ }^{3}$ \\ ${ }^{1}$ Faculty of Economics and Administration Sciences, Department of Business Administration, Süleyman Demirel \\ University, Isparta, Turkey. \\ ${ }^{2}$ Faculty of Economics and Administration Sciences, Department of Business Administration, Süleyman Demirel \\ University, Isparta, Turkey. \\ ${ }^{3}$ Faculty of Economics and Administration Sciences, Department of Business Administration, Süleyman Demirel \\ University, Isparta, Turkey. \\ Correspondence: Ferdi Akbiyik, Faculty of Economics and Administration Sciences, Department of Business \\ Administration, Süleyman Demirel University, Isparta, Turkey.
}

Received: March 21, 2016

doi:10.11114/ijsss.v4i5.1471
Accepted: April 5, $2016 \quad$ Available online: April 8, 2016

URL: http://dx.doi.org/10.11114/ijsss.v4i5.1471

\begin{abstract}
All visual, written and auditory contents designed according to the benefit of the consumers enable consumers to build a link between brand and product and therefore informative content regarding brand, business, product and services about the brand and the businesses themselves through digital channels can be defined as digital content marketing. Accordingly, companies are striving to create an effective and reliable content on the internet in order to gain new customers and secure existing ones. In this context, influencing consumers with content marketing is the main objective. The consumers realizing the content become the customer with the positive effect from the content. With the created content, customer satisfaction level is believed to increase as well. In the theoretical part of the study, a detailed review of the literature was presented concerning the definition of content and digital content marketing concepts, customer satisfaction factor in digital content marketing and its importance.

In the administration of the study, 3rd and 4th grade students studying in Business Administration in Süleyman Demirel University located in Isparta were used as samples and an analysis of the questions belonging to content marketing perception and the customer satisfaction scales in content marketing were conducted. According to the results of the research, it is seen that the accurate and reliable content created by businesses builds high satisfaction on customers. In addition, despite the low awareness of the concept of content marketing, consumers consider features of content marketing as a key element in meeting demands and needs they require.

As a result, it is understood that digital content marketing has a high significant impact on consumers, and it is thus a marketing type which needs to be focused on meticulously by brands or companies. The creation of customer loyalty with traditional marketing methods is rather difficult; however, understanding the customer, eliminating his/her needs and communicating with him/her become possible with the usage of digital content marketing. Because the aim is not to sell in digital content marketing but to stay in touch with frequent and potential customers.
\end{abstract}

Keywords: content, digital content marketing, customer satisfaction

\section{Introduction}

The rapid development of technology influenced the use of internet positively and allowed the use of it in many areas. Reaching the desired information at any time and from anywhere, the opportunity to access to a wide audience via internet had marketers make use of this delicate field. The quick rise of shopping over the internet led to the development of different strategies in terms of marketing.

Today, because the consumers have become more knowledgeable about products and thus their expectations from manufacturers have increased, their decision-makings and buying styles vary. The consumers like to look at many different websites in which they plan to make comparisons regarding the best qualifed yet the cheapest product they would purchase. Moreover, they check other users' comments and thoughts for the product in e-commerce cites, blog or 
forums so that they shall have information on the perception of the product. Determining customers' requests, expectations and needs properly play a dramatic role for the success of marketing over the internet (Yayla, 2010:13). Therefore, the companies also aim to gain consumers by responding their demands and expectations. By enabling the information the consumers wish to have regarding the product, the companies may secure the existing consumers and even retain potential new ones. The companies wishing to meet consumers' needs and expectations therefore prefer digital content marketing whose objectives are for the product.

Although digital marketing dates back to the 1890s, its becoming active and acceptance by the companies as a strategy started with the beginning of the 1990s (Pulizzi, 2012:1-3). With the increased awareness and expectations, the consumers regard such factors as innovation, diversity and design to be key factors. In order to provide sufficent information for the consumers about the innovative products, the companies may head for digital marketing as basic marketing strategy. The consumer reaching the content created for the product converts the information, which is obtained by the mentioned content, into the loyalty.

While the companies dedicate $25 \%$ of their all marketing budgets to content marketing (Content Marketing Institute,2014), the awareness of the importance of content marketing remains low in Turkey. Namely, whereas there are many detailed content, many consumer reviews and many videos in such e-commerce websites as Amazon, e bay and craigslit which sell products worldwide, the number of such strategies in the local e-commerce sites is limited. When we examine the domestic and foreign web sites selling the same product, those foreign web sites paying great attention to content marketing have many more reviews and scores concerning the product as they have a great deal of content marketing and they are quite comprehensive as such. However, the number of content and its sharing, created by the consumers themselves, in social media, blogs, and forms appear to be higher than the companies in Turkey. As understood from the tendency of consumers towards creating content, the content is demanded by the consumers themselves.

The most essential element in ensuring consumer satisfaction is content marketing and building the confidence depends on the accuracy and benefits of the content presented. The content which does not base on correct information will create consumer dissatisfaction. As mentioned before, the content is created by both companies and consumers. The deceptive content will result in the creation of negative perception among consumers towards companies

Today, with the transference of the power from manufacturer to consumer, the companies have to produce the product according not for their wishes but for the consumers' desires. The content marketing is the most appropriate marketing strategy in determining the product the consumer wish. Besides, the content marketing may increase customer satisfaction by educating, informing and entertaining the consumers. Those $78 \%$ of companies using content marketing see it as the marketing concept of the future (demandmetric.com).

In the literature, there are many studies examining the attitudes and behaviors of customers for purchases made over the internet. The purpose of this study is different from other studies in that it aims to explore satisfaction behavior of the customers, shopping on the internet, towards the websites appyling digital content marketing. In the study, a number of such factors as content and digital content concept, the aspect of customer satisfaction in digital content marketing were addressed.

\section{The Concept of Content, Digital Content Marketing Concept and Its Functions}

Content marketing and content strategy elements are different from each other (Rose, 2013). Content marketing can be defined as the creation and dissemination of valuable and relevant content in order to build a long-term relationship to attract target group and thus gain them whose demands and expectations are clearly defined and understood. Accordingly, content strategy is a concept prepared to strengthen ties between customers and companies and it also details product's features, functions and differences. The prepared content not only shall be entertaining and inspiring but also it should form talks about the product and donates new information to the customer (Hanbury, 2011).

While creating content, it should be forrmed according to which media direction it shall be used in (social media, blogs, magazines, etc). Because these environments are different from each other and so are their user profiles. Therefore, it would be different for the prepared content to be accepted and perceived by the users.

\section{The prepared content shall be;}

- Shareable,

- Easy to understand,

- Incentive,

- Easily accessible,

-Absorbing (Leibtag, 2011) 
While content is being prepared, analyzing target customers and driving their attention are essential factors. That the prepared content is innovative, enjoyable, and bears unusual features is important in terms of adoption and dissemination of this content (Swenk, 2014).

As already mentioned before, content marketing is created in order to attract and bound tie with the target customers, whose demands and expectations were clearly idendifed, by means of several factors. With the help of valuable content creation, the customers are tried to be directed as required. Besides, content marketing is also can be defined as the process of creating continuous value through which customer behaviors can be changed and directed (Pulizzi ve Barret, 2009). Similarly, digital content marketing is creation of awareness with the customers towards products and services by drawing attention of target group and potential customers; building content suitable for the demands of the customers and distribution of content via digital channels (Penpece, 2013:54).

Digital content marketing is also used in marketing strategies, in which page designs, graphics, texts and videos are found, which are informative, create value for the product and make consumer a customer. All these things are created with the help of content marketing for the products which the companies think to market either online or offline. The customers find it easy to get the information about the product they wish to buy thanks to high access level of technology. Digital content marketing is therefore intended to establish a relationship based on trust and communication by responding consumers' demands (Karkar, 2015:4).

We can give the following examples for a better understanding of the digital content marketing techniques. A brand manufacturing cell phone can offer a phone on the market, which emits zero radiation, so as to draw attention of consumers who pay attention to the wellness criteria. In addition, a company manufacturing, unlike its competitors, camcorder or comera may introduce some new products which are waterproof, high-quality recording under vibration; provide WI-FI and GPS and recharge itself using solar energy, and with help of digital content marketing through which the demands of the consumers are taken into consideration and thus the product shall be promoted.

The aim of digital content marketing is to transmit the original and valuable content, which is impressive indeed, to the consumers and therefore help them to make the right decision. With the digital content marketing, the customers are provided with the precious information through which they may ged rid of complexities of marketing activities and so a positive impact is created in the minds of consumers by which a long-term customer loyalty is established and will be reinforced. In particular, it should be noted that content marketing has an educational structure and, therefore, focuses on communication rather than sales. As a result, it can be said that consumers want to change knowledge and experience with loyalty (Rahim and Clemens, 2012). Similarly Hillebrand (2014) argued that communicating with customers and maintaining this communication rather than promoting the sale of products should be one of the main objectives of content marketing.

The leading reason of businesses to use digital content marketing is to establish a qualified relationship with the consumers, and to help to build better marketing strategies. For this reason, the most commonly used content type is the written one; however, videos, infographics, etc. are used in forums (brightcove.com, 2013). Social media, web sites, news, blogs, etc. can be considered suitable for this type of content to be published and social media is the most widely used one (Sluis, 2014).

It is seen that with increasing use of digital marketing and social media, the budget allocated to marketing activities in these areas also appear to go up(Foruouzandeh et al, 2014). Besides, the development of the internet has led to an increase in digital content markets. The increase in digital markets has led to an increase in number of those using digital media. Moreover, the increasing number of digital market customers has also improved and increased the number of studies on the electronic channels (Azad et al, 2016:1).

\section{Customer Satisfaction Factor and Its Importance In Digital Content Marketing}

The increase in the rate of purchases made over the internet makes it necessary to ascertain how and why consumers prefer internet while shopping (Lin, 2007). Apart from the basic functions of a website, it should also use marketing activities which put emphasis on customer knowledge and satisfaction to achieve success. Online retailers may also increase customer satisfaction and loyalty with the information regulated according to customer requirement and with more affordable options alike (Verhoef, 2001).

The value created for the product is an important factor in the establishment of consumer satisfaction and plays an important role in fulfilling the consumer's purchasing condition. While determining size of the benefit regarding the product he/she is going to buy, the consumer gets reference from the valuable content generated for the product (Lin, 2003:205).

Basic elements of content marketing to ensure customer satisfaction are as followings;

- Innovation 
- Accuracy

- Confidence

- Fulfillment of expectations.

The realization of the intended consumer satisfaction depends on the effectiveness of prepared content marketing strategy.

Customer satisfaction has positive results for retailers in that it provides them with keeping the attention of the consumer for a long-term and spreading consumer satisfaction as word of mouth (Zeithaml, 2000). As the consumer has the opportuninty only when they get the product in the purchases made over the internet, the characteristics of sold products and their usage directions must be consistent with the instructions given on the site, for it is of great importance in terms of consumer satisfaction. When the purchased product meets the demands of consumer, his/her comments on the blogs and product page would be quite positive, which is of great importance for the company in terms of gaining new consumers.

The services offered by online retailers can be sorted into three categories: pre-sale, sale, post-sale (Liu and Arnett, 2000).

Pre-sale phase includes efforts to draw the attention of consumers by providing easy access to the reasonable prices. The online consumer purchase activity takes place in giving order and paying time. Post-sale phase covers transmission, solutions of problems and related services (Lin, 2007:3). With the valuable content, difference of the product, the innovative nature and the benefits from it may tried to be shown in social media, blogs, internet articles through which the consumer may move towards the product.

In post-sales phase, the valuable content which plays an important role when the customer chooses a product should be consistent with the previously provided content and it should be accurate as well. Whether the content created by consumers is positive or critical depends on the satisfaction provided to the consumer.

\section{Methodology}

In this section, some information was given concerning the purpose of the research, which is to measure customer satisfaction factor in digital content marketing, its importance, scope and research methodology.

\subsection{Purpose and Importance of Research}

The purpose of this research is to evaluate empirically impact of contents, used in digital content marketing, on satisfaction of consumers regardless of whether they shop online or not.

A face to face questionnaire method was applied in order to collect and evaluate data in the research. There are a total of 22 questions in the questionnaire. The first seven questions are about demographic characteristics of consumers and their perceptions regarding content marketing. The remaining questions were asked to measure the customer satisfaction factor in the digital content market. The questions of the research were created by adapting "customer satisfaction scale" of Swaen and Chumpitaz (2008) to digital content marketing. The respondents were asked to indicate their levels of participation in statements with a likert scale 1 for the lowest and 5 for the highest. In the scope of the research, the target audience were those students studying at Suleyman Demirel University, located in Isparta province.

As the implementation of the questionnaire to the all students is not possible, the questionnaire was randomly administered to the 3rd and 4th grade students studying in business administration, with the help of cluster sampling.

The data was collected from questionnaires conducted face-to-face, and reliability testing was performed to test the extent of reliabity of the data. Afterwards, the variables were found not to have exhibited a normal distribution and Mann-Whitney and Kruskal-Wallis $\mathrm{H}$ tests were applied which are non-parametric tests. Besides, a factor analysis was conducted to determine the relationship between the variables. SPSS 17.0 statistical analysis program was used in the implemantation of the analysis.

\subsection{Research Hypotheses}

The following hypotheses were developed in line with the objectives of the research;

Hypothesis 1: There is a significant difference between customer satisfaction and gender for content marketing in pre-sale phase.

Hypothesis 2:There is a significant difference between customer satisfaction and gender for content marketing during the sale phase.

Hypothesis 3:There is a significant difference between customer satisfaction and gender for content marketing after the sale phase. 
Hypothesis 4:There is a significant difference between customer satisfaction and income for content marketing in pre-sale phase.

Hypothesis 5:There is a significant difference between customer satisfaction and income for content marketing during the sale phase.

Hypothesis 6:There is a significant difference between customer satisfaction and income for content marketing after the sale phase.

Hypothesis 7:There is a significant difference between customer satisfaction and internet usage time for content marketing in pre-sale phase.

Hypothesis 8:There is a significant difference between customer satisfaction and internet usage time for content marketing during the sale phase.

Hypothesis 9:There is a significant difference between customer satisfaction and internet usage time for content marketing after the sale phase.

\section{Research Findings}

The responds the consumers gave were analyzed with SPSS 17 program. Demographic characteristics and internet usage frequency were taken into account. How much content marketing is known and demanded by the consumers and its effect on consumer satisfaction were all investigated in this application.

In the study, although those 79 participants (40.7 percent) hear about content marketing, only 51 participants (26.2 percent) know what the content marketing is indeed. This shows that the awareness of content marketing is low in Turkey. Given the fact that this research was conducted on the 3rd and 4th class students studying in The Department of Business Administration, it can be concluded that this ratio is much lower among common consumers in Turkey.

Table 1. Demographic Characteristics of Respondents

\begin{tabular}{|c|c|c|c|}
\hline & & n & $\%$ \\
\hline \multirow[b]{2}{*}{ Gender } & Woman & 68 & 35,1 \\
\hline & Man & 126 & 64,9 \\
\hline \multirow{4}{*}{ Monthly Income } & $0-499$ & 88 & 45,4 \\
\hline & $500-749$ & 40 & 20,6 \\
\hline & $750-999$ & 40 & 20,6 \\
\hline & 1000 and above & 26 & 13,4 \\
\hline \multirow{4}{*}{$\begin{array}{c}\text { Daily Internet Usage } \\
\text { Frequency }\end{array}$} & Less than 4 hours & 81 & 41,8 \\
\hline & 4-8 hours & 95 & 49,0 \\
\hline & $8-13$ hours & 11 & 5,7 \\
\hline & 13 hours and above & 7 & 3,6 \\
\hline \multirow{6}{*}{$\begin{array}{c}\text { Purposes of Internet } \\
\text { Usage }\end{array}$} & Communication & 147 & 75,8 \\
\hline & Research & 130 & 67,0 \\
\hline & News & 86 & 44,3 \\
\hline & Game & 56 & 28,9 \\
\hline & Shopping & 54 & 27,8 \\
\hline & Banking & 29 & 14,9 \\
\hline \multirow{6}{*}{$\begin{array}{l}\text { Frequency of } \\
\text { Shopping }\end{array}$} & Once a week & 12 & 6,2 \\
\hline & Once in a month & 31 & 16,0 \\
\hline & Several times a month & 20 & 10,3 \\
\hline & Quarterly & 14 & 7,2 \\
\hline & Several times a year & 75 & 38,7 \\
\hline & Never & 41 & 21,1 \\
\hline
\end{tabular}


In study, for 0-499 TL the income is 45.4 percent, for 500-749TL it is 20.6 percent, for $750-999 \mathrm{TL}$ it is 20.6 percent, for $1000 \mathrm{TL}$ and above it is 13.4 percent respectively.

In the study, it was also seen that the percent of participants using internet for less than four hours was 41.8, for 4-8 hours it was 41.0, for 8-13 hours it was 5.7 and for more than 13 hours it was 3.6.

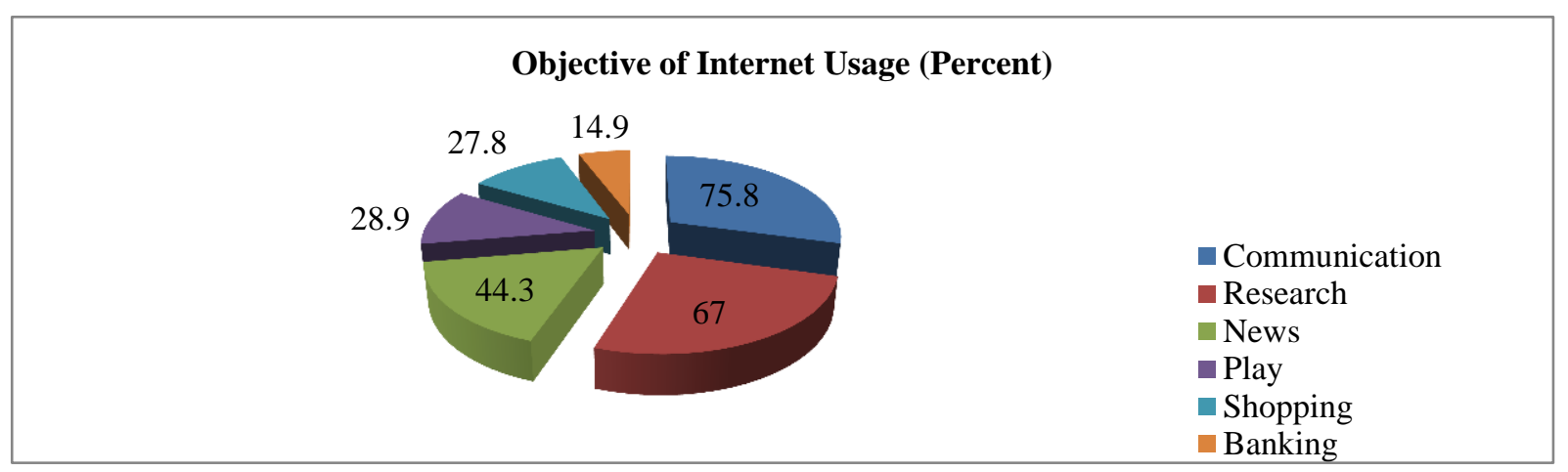

Figure 1. Objectives of Participants to Use Internet

The internet's usage aims of participants are as follows: 75.8 percent for communication, 67.0 percent for research, 44.3 percent for news, 28.9 percent for play, 27.8 percent for shopping and 14.9 percent for banking respectively.

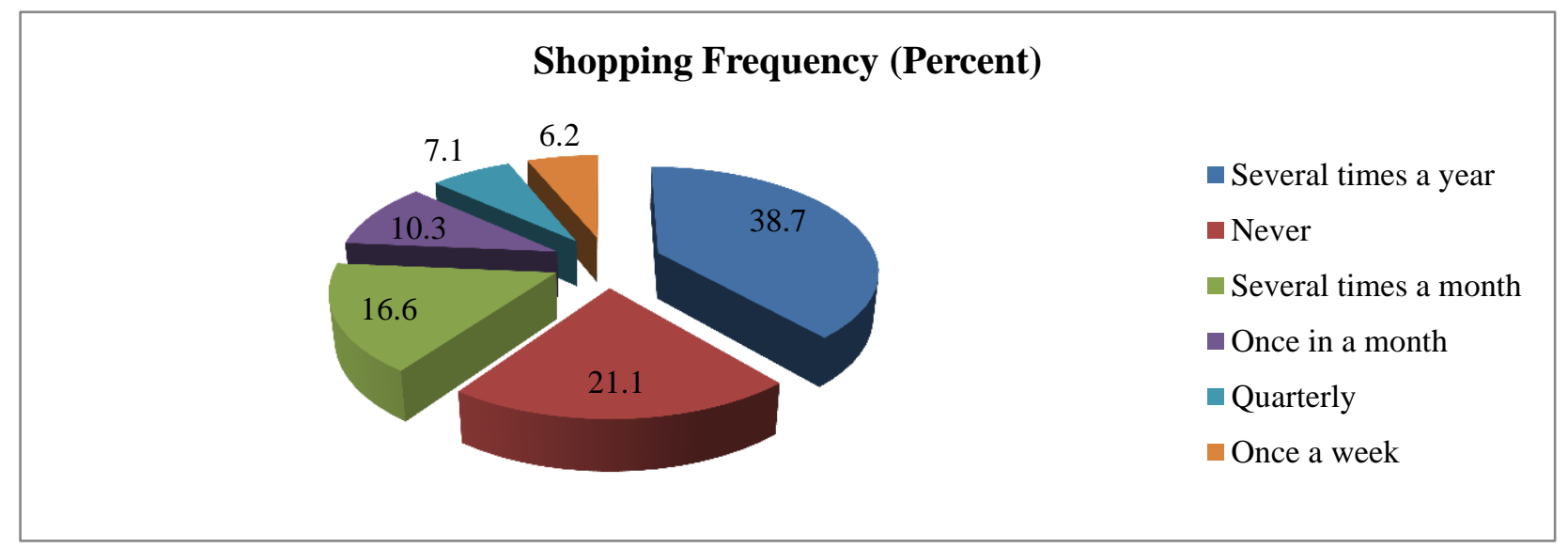

Figure 2. Shopping Frequency of Participants

The participants' freguency of shopping on the internet is 38.7 percent for several times a year, 21.1 percent for never, 16.6 for once a month, 10.3 for several times a month, 7.1 for quarterly and 6.2 for once a week respectively.

Table 2. The relationship between gender and satisfaction level for content marketing

\begin{tabular}{llcccc}
\hline & Gender & N & Mean Rank & MW & p \\
\hline Pre-sale & Man & 126 & 97,46 & 4279,500 & 0,990 \\
Wale & Woman & 68 & 97,57 & & 0,105 \\
& Man & 126 & 101,90 & 3729,00 & \\
Post-sale & Woman & 68 & 89,34 & & \\
& Man & 126 & 95,24 & 3999,500 & 0,444 \\
& Woman & 68 & 101,68 & & \\
\hline
\end{tabular}

According to the Mann-Whitney $U$ test results carried out to determine whether there is a significant difference between genders of participants and their satisfaction level for content marketing:

There is no significant difference between gender and satisfaction level, which is seen in pre-sale phase, for content marketing (Mann Whitney $\mathrm{U}=4279,500 ; \mathrm{p}=0,990>0,05$ ).

There is no significant difference between gender and satisfaction level, which is seen during sale phase, for content marketing (Mann Whitney $\mathrm{U}=3729,000 ; \mathrm{p}=0,105>0,05$ ). 
There is no significant difference between gender and satisfaction level, which is seen in post-sale phase, for content marketing (Mann Whitney $U=3999,500 ; p=0,444>0,05$ ).

Table 3. The relationship between monthly income and satisfcation level for content marketing

\begin{tabular}{lccccc}
\hline Income & N & $\begin{array}{c}\text { Mean } \\
\text { Rank }\end{array}$ & KW & p \\
\hline Pre-sale & $0-499$ & 88 & 102,40 & & \\
& $500-749$ & 40 & 97,85 & 1,824 & 0,610 \\
& $750-999$ & 40 & 89,50 & & \\
Sale & 1000 and above & 26 & 92,67 & & \multirow{2}{*}{0,391} \\
& $0-499$ & 88 & 91,71 & 3,004 & \\
Post-sale & $500-749$ & 40 & 107,15 & & \\
& $750-999$ & 40 & 96,13 & & \\
& 1000 and above & 26 & 104,37 & & \\
& $0-499$ & 88 & 88,20 & 4,859 & \\
& $500-749$ & 40 & 100,94 & & \\
& $750-999$ & 40 & 106,88 & & \\
& 1000 and above & 26 & 109,25 & & \\
\hline
\end{tabular}

According to the Kruskal-Wallis H-Test results conducted to determine whether there is a significant difference between income of participants and their satisfaction level for content marketing:

There is no significant difference between income and satisfaction level, which is seen in pre-sale phase, for content marketing $(\mathrm{KW}=1,824 ; \mathrm{p}=0,610>0,05)$.

There is no significant difference between income and satisfaction level, which is seen during sale phase, for content marketing $(\mathrm{KW}=3,004 ; \mathrm{p}=0,391>0,05)$.

There is no significant difference between income and satisfaction level, which is seen in post-sale phase, for content marketing $(\mathrm{KW}=4,859 ; \mathrm{p}=0,182>0,05)$.

Table 4. The relationship between shopping frequency and satisfaction level for content marketing

\begin{tabular}{llcccc}
\hline & Shopping Frequency & N & Mean Rank & KW & p \\
\hline Pre-sale & Once a week & 12 & 99,63 & & \\
& Once a month & 31 & 92,77 & & \\
Several times a month & 20 & 84,75 & \multirow{2}{*}{2,139} & 0,830 \\
Quarterly & 14 & 103,57 & & \\
Sale & Neveral times a year & 75 & 101,69 & & \\
& Once a week & 41 & 94,59 & & \\
& Once a month & 12 & 131,33 & & \\
& Several times a month & 31 & 93,58 & & \\
& Quarterly & 14 & 93,48 & \multirow{2}{*}{6,486} & \\
Post-sale & Several times a year & 75 & 97,89 & & \\
& Never & 41 & 89,71 & & \\
& Once a week & 12 & 129,54 & & \\
& Once a month & 31 & 108,79 & & \\
& Several times a month & 20 & 91,85 & \multirow{2}{*}{8,504} & \\
& Quarterly & 14 & 108,18 & & \\
& Several times a year & 75 & 87,50 & & \\
& Never & 41 & 94,63 & & \\
\hline
\end{tabular}


According to the Kruskal-Wallis H-Test results conducted to determine whether there is a significant difference between shopping frequency of participants and their satisfaction level for content marketing:

There is no significant difference between shopping frequency and satisfaction level, which is seen in pre-sale phase, for content marketing $(\mathrm{KW}=2,139 ; \mathrm{p}=0,830>0,05)$.

There is no significant difference between shopping frequency and satisfaction level, which is seen during sale phase, for content marketing $(\mathrm{KW}=6,486 ; \mathrm{p}=0,262>0,05)$.

There is no significant difference between shopping frequency and satisfaction level, which is seen in post-sale phase, for content marketing $(\mathrm{KW}=8,504 ; \mathrm{p}=0,131>0,05)$.

Table 5. Acceptance / Rejection Status of the Research Hypotheses

\begin{tabular}{|c|c|}
\hline Hypotheses & Status \\
\hline $\begin{array}{l}\text { Hypothesis 1: There is a significant difference between customer satisfaction and gender for content } \\
\text { marketing in pre-sale phase. }\end{array}$ & Rejected \\
\hline $\begin{array}{l}\text { Hypothesis } 2 \text { : There is a significant difference between customer satisfaction and gender for content } \\
\text { marketing during the sale phase. }\end{array}$ & Rejected \\
\hline $\begin{array}{l}\text { Hypothesis } 3 \text { : There is a significant difference between customer satisfaction and gender for content } \\
\text { marketing after the sale phase. }\end{array}$ & Rejected \\
\hline $\begin{array}{l}\text { Hypothesis } 4 \text { : There is a significant difference between customer satisfaction and income for content } \\
\text { marketing in pre-sale phase. }\end{array}$ & Rejected \\
\hline Hypothesis 5:There is a significant difference between customer satisfaction and income for content & Rejected \\
\hline marketing during the sale phase. & \\
\hline $\begin{array}{l}\text { Hypothesis 6: There is a significant difference between customer satisfaction and income for content } \\
\text { marketing after the sale phase. }\end{array}$ & Rejected \\
\hline Hypothesis 7: There is a significant difference between customer satisfaction and internet usage time & Rejected \\
\hline for content marketing in pre-sale phase. & \\
\hline $\begin{array}{l}\text { Hypothesis } 8 \text { : There is a significant difference between customer satisfaction and internet usage time } \\
\text { for content marketing during the sale phase. }\end{array}$ & Rejected \\
\hline Hypothesis 9: There is a significant difference between customer satisfaction and internet usage time & Rejected \\
\hline content marketing after the sale phase. & \\
\hline
\end{tabular}

Factor analysis is done to reduce the number of variables available. Factor analysis is defined as a statistical analysis method which provides interpretation and summary of meaningful data depending on the relationship seen among many variables (Altunışık, 2012: 264).

In the questionnaire, there are 15 questions which would be subjected to factor analysis. Firstly, KMO and Bartlett's tests were performed in order to test the suitability of the data for factor analysis. 
Table 6. KMO and Bartlett's Test

\begin{tabular}{lrr}
\hline Kaiser-Meyer-Olkin Measure of Sampling Adequacy. &, 847 \\
\hline \multirow{3}{*}{ Bartlett's Test of Sphericity } & Approx. Chi-Square & 1034,295 \\
& df & 78 \\
& Sig. &, 000 \\
\hline
\end{tabular}

When KMO vaules are between 09,90-1,00, it is accepted as excellent, between 0.80 to 0.89 it is very good (great), between 0.70 to 0.79 it is considered to be good respectively (Akgül ve Çevik, 2003:456). Accordingly, value of KMO, which was 0.816 in the applied factor analysis, was determined to be very good. Likewise, the sigma result of Barlett test was at 0.00 value which could be understood to be significant. In this study, it is therefore seen that the used data set was suitable for the application of factor analysis.

Table 7. Common Variance Table (Communalities)

\begin{tabular}{lll}
\hline & At Start & When removed \\
\hline Question 1 & 1,000 &, 568 \\
Question 2 & 1,000 &, 746 \\
Question 3 & 1,000 &, 751 \\
Question 4 & 1,000 &, 636 \\
Question 6 & 1,000 &, 757 \\
Question 7 & 1,000 &, 677 \\
Question 8 & 1,000 &, 753 \\
Question 9 & 1,000 &, 611 \\
Question 10 & 1,000 &, 514 \\
Question 11 & 1,000 &, 457 \\
Question 12 & 1,000 &, 487 \\
Question 14 & 1,000 &, 529 \\
Question 15 & 1,000 &, 518 \\
\hline
\end{tabular}

According to the values given in Table 7, there is no item with any problem.

Table 8. Eigenvalues Statistics And The Percentage of Explained Variance

\begin{tabular}{lrrrrr}
\hline \multirow{2}{*}{ Component } & \multicolumn{3}{c}{ Initial Eigenvalue } & \multicolumn{2}{c}{ Converted Eigenvalue } \\
\cline { 2 - 5 } & \multicolumn{1}{c}{ Total } & \% Variance & Cumulative $\%$ & Total & \% Variance \\
\hline 1 & 4,934 & 37,955 & 37,955 & 4,934 & 37,955 \\
2 & 1,939 & 14,918 & 52,874 & 1,939 & 14,918 \\
3 & 1,133 & 8,712 & 61,586 & 1,133 & 8,712 \\
4 &, 811 & 6,241 & 67,827 & & \\
5 &, 795 & 6,117 & 73,944 & \\
6 &, 681 & 5,235 & 79,179 & \\
7 &, 620 & 4,766 & 83,945 & \\
8 &, 493 & 3,790 & 87,735 & & \\
9 &, 456 & 3,506 & 91,241 & & \\
10 &, 369 & 2,840 & 94,080 & & \\
11 &, 293 & 2,256 & 96,336 & & \\
12 &, 246 & 1,893 & 98,229 & & \\
13 &, 230 & 1,771 & 100,000 & \\
\hline
\end{tabular}


When the values in Table 8 are examined, the eigenvalue of item whose eigenvalue consists of 13 questions can be grouped under 3 factors whose eigenvalues are greater than 1 . These three factors explain the scale as $61.568 \%$ of the variance. This value was also determined to be an appropriate rate for factor analysis assumptions.

Table 9. Rotated Component Matrix

\begin{tabular}{|c|c|c|c|}
\hline & \multicolumn{3}{|c|}{ Component } \\
\hline & 1 & 2 & 3 \\
\hline $\begin{array}{l}\text { That the content provided to me by websites over which I do shopping is } \\
\text { accurate and reliable is important to me. }\end{array}$ & 829 & & \\
\hline $\begin{array}{l}\text { The websites over which I do shopping should excatly meet the information I } \\
\text { need. }\end{array}$ &, 824 & & \\
\hline $\begin{array}{l}\text { Cost-site service quality of the websites over which I do shopping should be } \\
\text { appropriate. }\end{array}$ & ,790 & & \\
\hline $\begin{array}{l}\text { The information given by the websites over which I do shopping should } \\
\text { always be available. }\end{array}$ &, 724 & & \\
\hline $\begin{array}{l}\text { The websites over which I do shopping should support the information they } \\
\text { give regarding the product with image, video and etc. }\end{array}$ & ,372 &, 777 & \\
\hline $\begin{array}{l}\text { The websites over which I do shopping should explain how the product's } \\
\text { design and usage forms is with visual content. }\end{array}$ & & ,756 & \\
\hline The websites over which I do shopping should provide valuable content. & & ,749 & \\
\hline $\begin{array}{l}\text { The websites over which I do shopping should provide detailed information } \\
\text { about product. }\end{array}$ & ,430 & ,744 & \\
\hline $\begin{array}{l}\text { While shopping on the internet, I spend more time in the websites offering } \\
\text { unusual information. }\end{array}$ & & & ,716 \\
\hline $\begin{array}{l}\text { I share the websites in which I do shopping, which provide valuable } \\
\text { information as well, on social media websites. }\end{array}$ & & & ,710 \\
\hline $\begin{array}{l}\text { I recommened the websites at least for one person, which provide valuable } \\
\text { information while I'm shopping. }\end{array}$ & & & ,705 \\
\hline $\begin{array}{l}\text { I benefit from the educational and innovative content about the product } \\
\text { which I encounter while shopping on the internet. }\end{array}$ & ,320 & &, 591 \\
\hline I reuse the websites offering valuable content when I need. & & ,307 & ,556 \\
\hline
\end{tabular}

When rotated component matrix in table 9 was examined, it was determined that the first factor of the scale consisted of 4 items, the second factor was made up of 5 items, and the third factor was composed of 4 items respectively. The four items formed by the first factor of the scale were named as "customer satisfaction level seen in pre-sale phase in content marketing", the five items formed by the second factor were named as "customer satisfaction level seen during sale phase in content marketing" and the four items formed by the third factor of the scale were named as "customer satisfaction level seen in post-sale phase in content marketing".

\section{Discussion and Conclusion}

In this research, the effects of content marketing, which is one of the new activities in the field of marketing, on customer satisfaction level were investigated. The 3rd and 4th grade students studying in school of Business Administration in Suleyman Demirel University were selected as the sample. The reason why this sample group was selected is that this group is accepted to be more knowledgeable about the marketing activities and their internet usage and shopping frequency realized on the internet seem higher. 200 questionnaires were performed; however, 196 of them were considered to be valid.

In research, it was found that there was no relationship between gender, age, income, internet usage time or shopping frequency on internet and customer satisfaction level provided by content marketing. In the scope of the research, it was also seen that 3 factors could be effective in decision making phase which are pre-sale, sale, and post-sale.

The satisfaction level for content marketing showed no significant difference on gender, income and shopping frequency.

The content created by the companies should be consistent with such factors as technology, innovation and value creation, for the accurate and valuable content may constitute a high consumer satisfaction. According to the results obtained from research, despite the low awareness of content marketing, it is demanded by consumers. However, both creation of digital content and sharing it in digital media by consumers is relatively low. 
The satisfaction level in content marketing was determined to show no significance in gender, income and frequency of shopping. But, while almost half of the participants heard about content marketing, $75 \%$ of those have not got a single idea what the content marketing is indeed. However, there are some issues to be considered here. Namely; consumers gather information about the product they buy online on companies' online media. And that information can influence the purchasing behavior of consumers. Ironically, the information the consumers collect is nothing but the content marketing itself. In other words, consumers are unwittingly exposed to content marketing. In this regard, the measures which can be taken by the companies so as to increase the satisfaction level of consumers can be listed below as:

- Identification of customer expectations and providing services accordingly,

- Conducting customer surveys at regular intervals,

- The creation of content to keep products in the forefront with impressive visuals and ensuring the distribution of it properly.

As a result, whether the consumers know what the content marketing is as such has of no great importance; but rather, what is important is that the given content should be encouraging for them to buy the product and meantime it shall have the quality to turn consumers into customers. Finally, the content marketing should provide companies with securing existing customers and it had better has the potantial to attract and gain new ones.

\section{References}

Azad, N., Mohsen, S., Akbar, S. A., \& Zomorodian, S. (2016). Factors Stimulation Content Marketing, Management Science Letters, 109-114.

DeLone, W. H., \& McLean, E. R., (2003). The DeLone and McLean model of information systems success. Journal of Management Information Systems, 19(4), 9-30

Elisa, R. \& Gordini, N., (2014). Content Marketing Metrics: Theoretical Aspects And Empirical Evidence, European Scientific Journal, 10(34), 92-104

Forouzandeh, S., Soltanpanah, H., \& Sheikhahmadi, A. (2014). Content marketing through data mining on Facebook social network. Webology, 11(1), 1

Handley, A., \& Chapman, C. C. (2010). Content Rules. New York: Wiley.

Hillebrand, S. (2014). Content Marketing in Social Networks. Embs - Unıversität Kassel, Master Thesis Exposé

Kaba R., \& Bechter C. (2012). Organizational Goals and Performance Measurement Criteria for Content Marketing. Journal of Communication and Computer, 9, 896-904

Karkar, A. (2016). Değer ve Güven Ağlarının Yükselişinde İçerik Pazarlaması. International Journal of Social Sciences and Education Research, 2(1), 334-348.

Lead Generation Marketing Effectiveness Study Examining Content Marketing, Au-tomation \& ROI 2013. Lenskold Group http://www.lenskold.com/content/LeadGenStudy_2013.html

Pool, L., (2013). New Research Shows Increasing Reliance on Content Marketing to Drive Brand Awareness, Inbound Traffic and Sales

Lin, C. C. (2003). A Critical Appraisal of Customer Satisfaction and E-commerce, Managerial Auditing Journal, 18(3): 202-212. http://dx.doi.org/10.1108/09604520210451911

Lin, H. F. (2007). The Impact of Website Quality Dimensions on Customer Satisfaction in the B2C E-commerce Context. Total Quality Management \& Business Excellence, 18(4), 363-378. http://dx.doi.org/10.1080/14783360701231302

Liua, C., \& Arnett, K. P. (1999). Exploring the Factors Associated with Web Site Suc-cess in the Context of Electronic Commerce. Journal of Information \& Man-agement, 38(1), 23-33. http://dx.doi.org/10.1016/S0378-7206(00)00049-5

Odden, L. (2012). How to Attract and Engage More Customers by Integrating SEO, Social Media and Content Marketing. New Jersey: Wiley.

Penpece, D. (2013). Dijital İçerik Pazarlaması,Karahan Kitabevi, 2013.

Pulizzi, J. (2012). The Rise of Storytelling as the New Marketing. Journal of Publishing Research Quarterly, 28(2), 116-123. http://dx.doi.org/10.1007/s12109-012-9264-5

Sluis, S. (2014). Social Media Leads Content Marketing. http://www.destinationcrm.com/Articles/Columns-Departments/Insight/Social-Media-Leads-Content-Marketing-9 
3715.aspx Erişim Tarihi: 24.03.2016

Verhoef, P. C., (2001). Possible Determinants of Consumers' Adoption of Electronic Grocery Shopping in the Netherlands. Journal of Retailing and Consumer Services, 8, 275-285

Zeithaml V. A. (2000). Service Quality, Profitability, and the Economic Worth of Customers: What We Know and What We Need to Learn, Journal of the Academy of Marketing Science, 28(1), 66-85. http://dx.doi.org/10.1177/0092070300281007

https://www.brightcove.com/en/company/press/new-research-shows-increasing-reliance-content-marketing-drive-brand -awareness-inbound-traffic-and-s / Access Date: 01.04.2016

http://contentmarketinginstitute.com/2013/10/content-strategy-content-marketingseparate- connected/ Access Date: 11.12.2015

http://contentmarketinginstitute.com/2011/02/content-mix/ Access Date: 17.12.2015

http://jasonswenk.com/creating-valuable-content/ Access Date: 04.01.2016

http://www.demandmetric.com/content/content-marketing-infographic Access Date: 15.02.2016

\section{(c) $\mathbf{E Y}$}

This work is licensed under a Creative Commons Attribution 3.0 License. 